\title{
Influence of Soil-Cement Composition on its Selected Properties
}

\author{
Krystian Brasse ${ }^{1, *}$, Tomasz Tracz ${ }^{1}$, Tomasz Zdeb ${ }^{1}$, Piotr Rychlewski ${ }^{2}$ \\ ${ }^{1}$ Cracow University of Technology, Faculty of Civil Engineering, ul. Warszawska 24, 31-155 \\ Kraków, Poland \\ ${ }^{2}$ Road and Bridge Research Institute, ul. Instytutowa 1, 03-302 Warszawa, Poland
}

\begin{abstract}
The paper discusses the results of mechanical and technological tests of soil-cement composites made with cohesive soil. The compositions of analysed soil-cement mixtures differed in terms of their cement paste volume fractions and water-cement ratios. Limiting values of these technological parameters that enable the application of the soil-cement mixtures obtained in real life conditions for the purposes of the Deep Soil Mixing (DSM) method were determined. Based on the test results obtained, it was found that mechanical properties of the materials analysed were very sensitive to changes in their compositions. Variations in the volume fraction of cement paste within the range analysed caused mechanical properties to change even by an order of magnitude.
\end{abstract}

\section{Introduction}

Unfavourable soil conditions for erecting structures are an increasingly frequent difficulty associated with new investment projects. One solution is to reinforce the underlying soil so that it can become an integral part of new civil engineering structures. New soil improvement techniques and the development of technologies related to geotechnical engineering materials have resulted in many methods that can be used to reinforce weak soil substrate. However, an important consideration is that the modification of geotechnical properties of soils should allow for their efficient and rational use as a foundation for new construction projects. Thus desired characteristics of the solutions to be adopted are simplicity, lower implementation costs and environmental friendliness [1-3]. These requirements can be met by in-situ mixing of soil, since it enables the direct modification of its properties, above all strength, plasticity and tightness, without the need for bringing the soil to the surface. As a result of the soil being mixed with binding material, it is strengthened through the chemical reactions that occur. In this way, a new material with the desired mechanical properties is obtained after adding the stabiliser. Most commonly used stabilisers are mineral binders such as cement and lime $[1,2]$, but the range of materials which can be used is wide - from fly ash through slags, bitumens and resins to bentonite. Specially developed mixtures that consist of several of the aforementioned materials can also be used for reinforcing weak soils [2].

\footnotetext{
*Corresponding author: krystian.brasse@pk.edu.pl
} 
These methods have undoubtedly seen more use and have been steadily developed in recent decades thanks to the numerous advantages of the in-situ deep soil mixing technology. The choice of the reinforcement method as well as the choice of the type of stabiliser used depends on the type of the soil to be reinforced. It should be stressed that these stabilisers can be used both with non-cohesive and cohesive soils [3-6]. Soil reinforcement itself may be conducted on the surface or in an in-depth manner. Surface stabilisation is mainly used in road construction, but also in general and industrial construction. It consists in mixing the upper soil layer with a stabiliser (usually cement) and subsequently compacting it $[2,7]$. More often, however, deep soil reinforcement technology is used; in many countries, it is synonymous with the very popular Deep Soil Mixing (DSM) method developed in the U.S. in the 1980s [1]. Additionally, in the in-situ soil mixing technology there are two ways of adding the binding material - dry or wet mixing $[1,2]$. "Dry" deep soil mixing is used to reinforce highly hydrated or organic soils $[5,6]$. The reinforcement is in the form of columns formed by mixing the soil with the stabiliser in powdered form; they are referred to as DSMdry columns [7]. It should be stressed, however, that the DSM-dry technology is not widely used in Poland, mostly due to the difference in the quality of the final product compared to the one obtained using the DSM-wet deep soil mixing method [5]. This technology differs primarily in the method of adding binder to the soil - it is fed together with water in the form of paste. This method is described in detail, inter alia, in $[4,8,9,10]$.

Nevertheless, in spite of its many advantages, the DSM technology does have some disadvantages, e.g. the degree of reinforcement obtained often varies considerably [11]. Among the factors that affect the reinforcement effect are the physical and chemical properties of the reinforced soil, the properties of the binder, additives and water as well as the mixing technique and conditions and the setting time and conditions [12]. Therefore, new projects require not just experience and practice, but also proper engineering design. For this purpose, one must know local soil conditions and the assumed strength criteria for the proposed reinforcement as well as be aware of technical capabilities of the equipment used and economic aspects of the project [13]. In the case of the DSM technology, based on practice and experience, attempts are made to document various principles and aspects of designing DSM columns [11, 14].

In practice, there are no standardized requirements for the strength of soil-cement composites, but their mechanical parameters result directly from the loads occurring in the structure. It should be emphasized that, for example, DSM columns cooperate with the surrounding soil and their strength must be only greater than the soil. The most common compressive strength of discussed composites ranges from 2 to $5 \mathrm{MPa}$. Higher values can be achieved in case of non-cohesive soils and smaller ones in cohesive. In engineering practice, the minimum strength is about 2-2.5 MPa, however, it cannot be ruled out that the required strength will be less as a result of structural calculations [10].

Observations from engineering practice indicate that technological considerations often determine the composition of soil-cement. This means that the amount of cement paste pumped in during soil mixing and its liquidity very often result from the need to obtain a homogeneous mixture, and its consistency must be adapted to the efficiency of mixing devices. The very rapidly growing segment of deep soil mixing machinery and the increasingly common trench-mixing method offer greater possibilities of controlling this process. In summary, modern mixing methods make it possible to obtain homogeneous mixtures with a broader range of acceptable cement paste amounts or liquidities.

\section{Study objective}

This paper presents the results of research aimed at determining the influence of the composition of soil-cement designed and produced under laboratory conditions on its 
selected properties. The information obtained should help determine the relationships that can be used when designing soil-cement compositions in order to achieve the desired properties of hardened composites. Designing the composition of soil-cement and studying its effect on (mainly mechanical) soil properties is important insofar that it allows to obtain appropriate levels of virgin soil reinforcement.

\section{Materials}

The research programme involved producing a series of soil-cement composites whose compositions varied in terms of the amount of cement paste $V_{z}$ used and water-cement (w/c) ratios. Cohesive soil identified as clay was selected for producing the composites. The soilcement compositions tested were created as a result of mixing the virgin soil described in Table 1 with CEM II/B-S $32.5 \mathrm{R}$ cement paste with the properties stated in Table 2.

Table 1. Properties of the clay selected.

\begin{tabular}{|c|c|}
\hline Properties & Value \\
\hline $\begin{array}{l}\text { Particle size distribution [\% by mass] } \\
\text { - gravel fractions } 2 / 40 \mathrm{~mm} \\
\text { - sand fractions } 0.05 / 2 \mathrm{~mm} \\
\text { - dust fractions } 0.002 / 0.05 \mathrm{~mm} \\
\text { - clay fractions }<0.002 \mathrm{~mm} \\
\end{array}$ & $\begin{array}{l}- \\
40 \\
42 \\
18\end{array}$ \\
\hline Bulk density @ [g/cm3] & 2.10 \\
\hline Bulk density of the soil skeleton $\mathrm{gd}\left[\mathrm{g} / \mathrm{cm}^{3}\right]$ & 1.81 \\
\hline $\begin{array}{l}\text { Maximum bulk density of the soil skeleton gdmax } \\
{\left[\mathrm{g} / \mathrm{cm}^{3}\right]}\end{array}$ & 1.91 \\
\hline Natural moisture content $\mathrm{w}_{\mathrm{n} \text { mean }}[\%]$ & 15.81 \\
\hline Optimal moisture content $\mathrm{w}_{\text {opt }}[\%]$ & 11.1 \\
\hline Yield point $\mathrm{w}_{\mathrm{P}}[\%]$ & 15.32 \\
\hline Liquid limit $\mathrm{w}_{\mathrm{L}}[\%]$ & 25.8 \\
\hline Plasticity index $I_{L}[\%]$ & 0.05 \\
\hline Approximate content of $\mathrm{CaCO}_{3}[\%]$ & $1-3$ \\
\hline
\end{tabular}

Table 2. Properties of CEM II/B-S 32.5 R cement.

\begin{tabular}{|l|c|}
\hline Properties & Value \\
\hline Compressive strength after 2 days [MPa] & 18.0 \\
\hline Compressive strength after 28 days [MPa] & 49.0 \\
\hline Initial setting time [min] & 190 \\
\hline Water at normalised consistency [\%] & 28 \\
\hline Specific surface (Blaine) $\left[\mathrm{cm}^{2} / \mathrm{g}\right]$ & 3.570 \\
\hline
\end{tabular}

\section{Methods and test results}

To date, engineering activities involving the production of soil-cement structures have not been preceded by laboratory tests. The amount of paste and the w/c ratio of the soil-cement mix were conditioned by the need to obtain the appropriate consistency. When designing the composition of soil-cement, the workability of the mixture during mixing and its consistency after mixing should be adopted as boundary conditions. Mixtures were required to be selfcompacting with no segregation of ingredients. Hence different amounts of paste are used for 
different types of soil so as to obtain the consistency that allows the material produced to be used at the target location. In this manner, when designing soil-cement compositions, workability maps were developed for cement mixtures (Table. 3), showing the ranges of cement paste amounts $\mathrm{V}_{\mathrm{z}}$ and water-cement $(\mathrm{w} / \mathrm{c})$ ratios within which interesting compositions in terms of the properties expected can be sought. In the case of cohesive soils with the characteristics stated in Table 1, the range of cement paste volumes used was from 550 to $650 \mathrm{dm}^{3} / \mathrm{m}^{3}$. w/c ratio values ranged from 1.2 to 3.8 . Changes in the amount of paste added and in the $\mathrm{w} / \mathrm{c}$ ratios adopted involved differences in cement content for each mixture (in $\mathrm{kg} / \mathrm{m}^{3}$ ). In the case of the soil-cement mixtures tested, cement content ranged from 133 to $427 \mathrm{~kg} / \mathrm{m}^{3}$. In engineering practice, the most common cement mass fraction ranges from 300 to $400 \mathrm{~kg} / \mathrm{m}^{3}$. This amount results from a compromise between the achieved mechanical properties of soil-cement composite and the costs of its production. Summing up, 32 variants of soil-cement compositions were analysed.

Table 3. Map of workability of soil-cement composites made with cohesive soil.

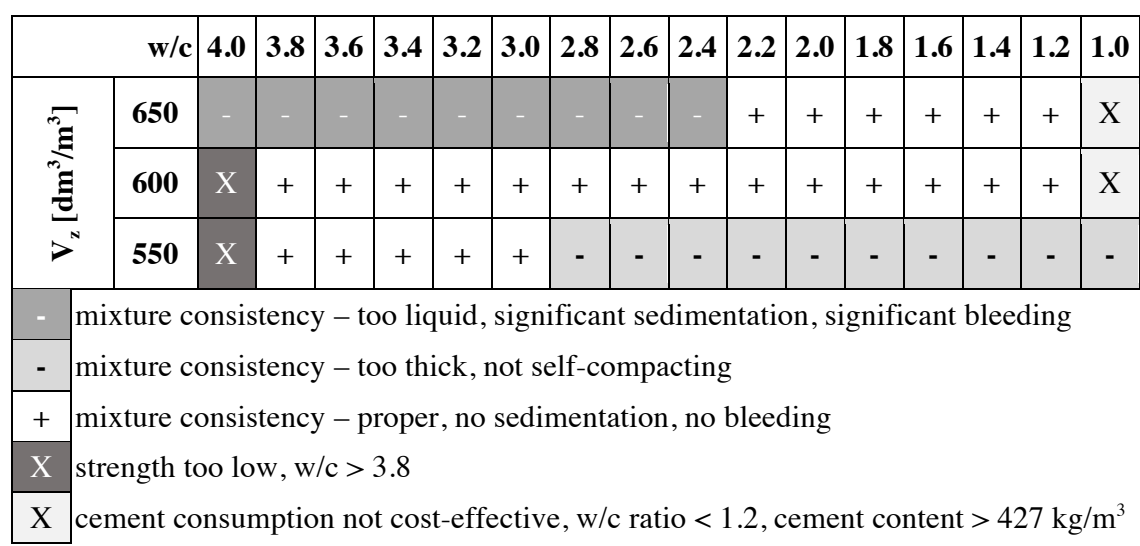

The scope of soil-cement tests covered the following properties: consistency determined on the basis of the mixture flow diameter measured by means of a flow table, flexural tensile strength determined for $100 \times 100 \times 500 \mathrm{~mm}$ prisms and compressive strength determined for $100 \mathrm{~mm}$ cubes cut from prism halves after bending. Tests of mechanical properties were conducted after 28 days of curing under laboratory conditions that prevented the evaporation of mixing water.

Fresh mix consistency tests were carried out in accordance with the standard EN 1015-3. This method consists in measuring the flow diameter of a portion of the mixture tested after shaking it several times on a table. Analysing the measurements conducted, it can be stated that in the case of the soil tested, mixtures with the appropriate consistency exhibited flow diameter values ranging from 170 to $230 \mathrm{~mm}$. The photographs below (Fig. 1, Fig. 2, Fig. 3) show three levels of mixture consistency obtained.

Tests of mechanical properties of hardened composites were conducted for 25 soilcement compositions selected on the basis of the consistency assessment conducted, after the mixtures that did not meet the required criteria had been rejected.

The flexural strength test was conducted in accordance with the standard EN 12390-5, which concerns testing concrete specimens placed on supporting pins with the constant spacing 1 equal to $3 \mathrm{~d}$, i.e. $300 \mathrm{~mm}$. The only deviation from the guidelines included in the standard was the reduction in the stress increase rate during the test to $0.01 \mathrm{MPa} / \mathrm{s}$ due to the differences in the expected strength of the material tested compared to the flexural strength of normal concrete. Flexural strength $\left(\mathrm{f}_{\mathrm{cf}}\right)$ results are summarised in Table 4 . Owing to the 
number of tests performed, partial results are not presented, and the results presented are limited to mean values from three measurements.

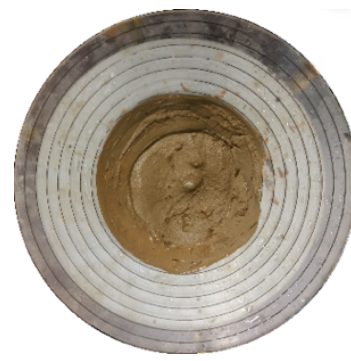

Fig. 1. Mixture consistency too thick:

- flow table $=155 \mathrm{~mm}$;

$-\mathrm{V}_{\mathrm{z}}=550 \mathrm{dm}^{3} / \mathrm{m}^{3} ; \mathrm{w} / \mathrm{c}=2.2$

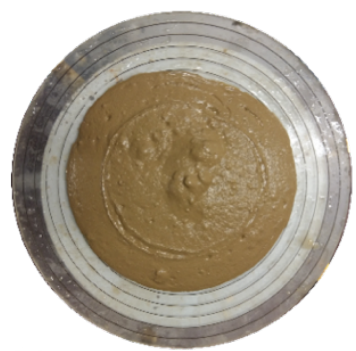

Fig. 2. Mixture consistency proper:

- flow table $=200 \mathrm{~mm}$;

$-\mathrm{V}_{\mathrm{z}}=600 \mathrm{dm}^{3} / \mathrm{m}^{3} ; \mathrm{w} / \mathrm{c}=2.4$

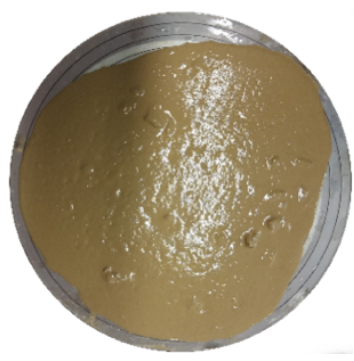

Fig. 3. Mixture consistency too liquid:

- flow table $=270 \mathrm{~mm}$;

$-\mathrm{V}_{\mathrm{z}}=650 \mathrm{dm}^{3} / \mathrm{m}^{3} ; \mathrm{w} / \mathrm{c}=2.6$

Table 4. Results of flexural strength $\left(f_{c f}\right)$ tests for specimens after 28 days of curing in MPa.

\begin{tabular}{|c|c|c|c|c|c|c|c|c|c|c|c|c|c|c|c|c|c|}
\hline \multicolumn{2}{|r|}{ w/c } & 4.0 & 3.8 & 3.6 & 3.4 & 3.2 & 3.0 & 2.8 & 2.6 & 2.4 & 2.2 & 2.0 & 1.8 & 1.6 & 1.4 & 1.2 & 1.0 \\
\hline \multirow{3}{*}{${ }_{D^{N}}^{\stackrel{m}{\xi}}$} & 650 & - & - & - & - & & - & - & - & - & 0.8 & 0.8 & 1.0 & 1.2 & 1.5 & 2.0 & X \\
\hline & 600 & X & 0.4 & 0.4 & 0.4 & 0.4 & 0.4 & 0.7 & 0.8 & 0.8 & 1.0 & 1.1 & 1.2 & 1.5 & 1.8 & 2.0 & $X$ \\
\hline & 550 & $\mathrm{X}$ & 0.5 & 0.5 & 0.6 & 0.6 & 0.7 & - & - & - & - & - & - & - & - & - & - \\
\hline
\end{tabular}

The chart below (Fig. 4) shows the effect of cement paste amount and of the w/c ratio on the flexural strength of soil-cements based on cohesive virgin soil after 28 days of curing.

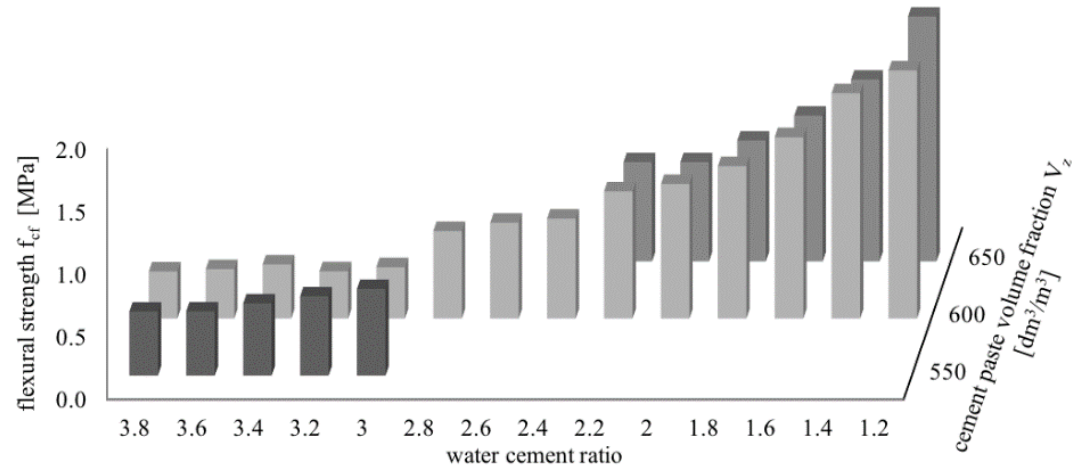

Fig. 4. Flexural strength chart depending on the water-cement ratio and cement paste volume fraction after 28 days of curing.

The flexural strength values obtained after 28 days of curing ranged from 0.4 to $2.0 \mathrm{MPa}$. The analysis of results points to an increase in flexural strength achieved by soil-cement as the $w / c$ ratio decreases. Additionally, it was observed that as the amount of cement paste added $\mathrm{V}_{\mathrm{z}}$ decreased for a given $\mathrm{w} / \mathrm{c}$ ratio, there was a slight increase in the strength of the soil-cement mixtures tested.

The compressive strength test was conducted in accordance with the standard EN 12390-3, which also concerns testing concrete specimens. Again, the only deviation from 
the guidelines included in the standard was the reduction in the stress increase rate during the test to $0.05 \mathrm{MPa} / \mathrm{s}$. Compressive strength $\left(\mathrm{f}_{\mathrm{c}}\right)$ results are summarised in Table 4 . Similarly as before, the results presented are mean values from three measurements.

The chart below (Fig. 5) shows the effect of variable cement paste amounts and various values of the w/c ratio on the compressive strength of soil-cements based on cohesive virgin soil after 28 days of curing.

Table 5. Results of compressive strength $\left(\mathrm{f}_{\mathrm{c}}\right)$ tests for specimens after 28 days of curing in MPa.

\begin{tabular}{|c|c|c|c|c|c|c|c|c|c|c|c|c|c|c|c|c|c|}
\hline \multicolumn{2}{|r|}{$\mathbf{w} / \mathbf{c}$} & 4.0 & 3.8 & 3.6 & 3.4 & 3.2 & 3.0 & 2.8 & 2.6 & 2.4 & 2.2 & 2.0 & 1.8 & 1.6 & 1.4 & 1.2 & 1.0 \\
\hline \multirow{3}{*}{ 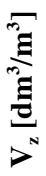 } & 650 & - & - & - & - & - & - & - & - & - & 2.9 & 3.7 & 4.3 & 4.9 & 6.5 & 10.2 & $X$ \\
\hline & 600 & $X$ & 1.2 & 1.4 & 1.5 & 1.5 & 1.7 & 2.8 & 2.6 & 3.2 & 3.6 & 4.6 & 5.0 & 6.5 & 6.1 & 10.8 & $X$ \\
\hline & 550 & $\mathrm{X}$ & 1.6 & 1.8 & 1.7 & 2.2 & 2.5 & - & - & - & - & - & - & - & - & - & - \\
\hline
\end{tabular}

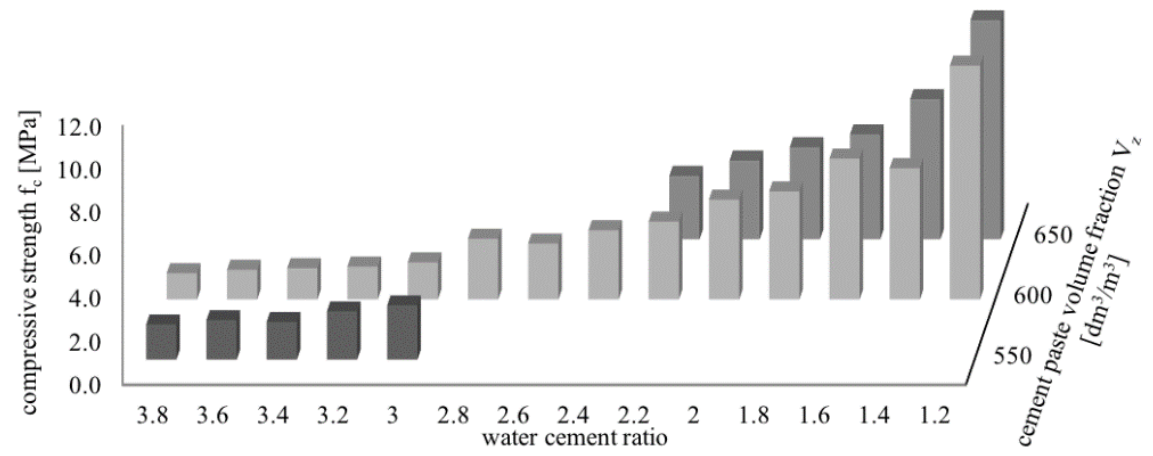

Fig. 5. Compressive strength chart depending on the water-cement ratio and cement paste volume fraction after 28 days of curing.

For compressive strength after 28 days, the range of results obtained ranged from 1.2 to $10.8 \mathrm{MPa}$. Analysing the effect of changes in cement paste content $\mathrm{V}_{\mathrm{z}}$ and $\mathrm{w} / \mathrm{c}$ ratio on the results obtained, it can be stated again that reducing both the cement paste content $\mathrm{V}_{\mathrm{z}}$ and the w/c ratio results in an increase in the compressive strength of the composites tested.

In order to make the test results obtained useful for the practical design of soil-cement from cohesive soil exhibiting the properties presented in Table 1, an attempt was made to determine the correlation between soil-cement composition and the properties of the composite obtained. The chart below (Fig. 6) shows the effect of w/c ratio on compressive strength after 28 days of curing. It has been observed that the power function matches the variation presented very well. Owing to the clear impact of the amount of cement paste on the strength of soil-cement, it was decided that three such functions should be determined:

$$
\begin{array}{ll}
-f_{c}=18.48 \mathrm{w} / \mathrm{c}^{-1.81} & \text { is applicable to w/c } 3.8 \div 3.0 \text { with } \mathrm{V}_{\mathrm{z}}=550 \mathrm{dm}^{3} / \mathrm{m}^{3} \\
-\mathrm{f}_{\mathrm{c}}=16.12 \mathrm{w} / \mathrm{c}^{-1.92} & \text { is applicable to w/c } 3.8 \div 1.2 \text { with } \mathrm{V}_{\mathrm{z}}=600 \mathrm{dm}^{3} / \mathrm{m}^{3} \\
-\mathrm{f}_{\mathrm{c}}=13.23 \mathrm{w} / \mathrm{c}^{-1.93} & \text { is applicable to w } / \mathrm{c} 2.2 \div 1.2 \text { with } \mathrm{V}_{\mathrm{z}}=650 \mathrm{dm}^{3} / \mathrm{m}^{3}
\end{array}
$$

The power functions determined reflect the results obtained very accurately as evidenced by very high values of determination coefficients, which range from 0.976 to 0.995 .

Seeking to simplify the description by making the compressive strength of soil-cement dependent on a single composition parameter, the chart in Fig. 7 only shows the effect of the amount of cement on strength. It turns out that this relationship is indeed present and can be successfully described by using a linear function, since the amount of cement results from 
the assumed w/c ratio and the amount of cement paste and thus is a universal parameter of soil-cement composition.

Moreover, flexural strength was compared to compressive strength (Fig. 8) and it was observed that the proportion between these two values is around 0.2 and is independent of the strength figures compared.

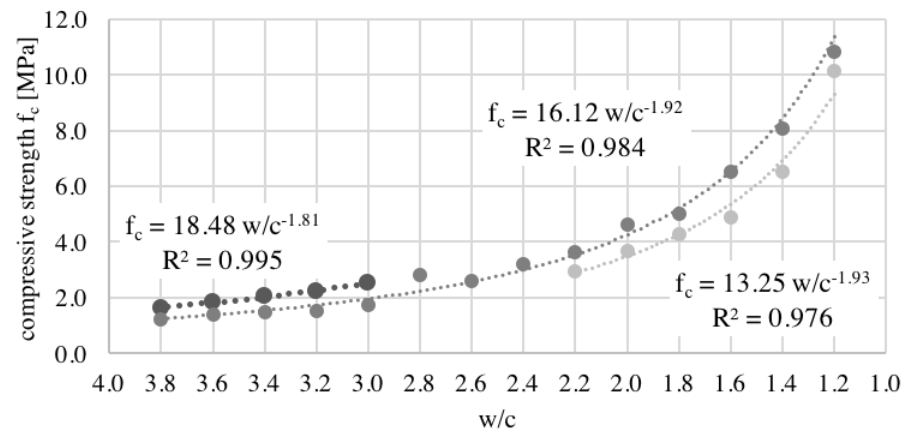

Fig. 6. Compressive strength chart depending on the water-cement ratio and cement paste volume fraction after 28 days of curing.

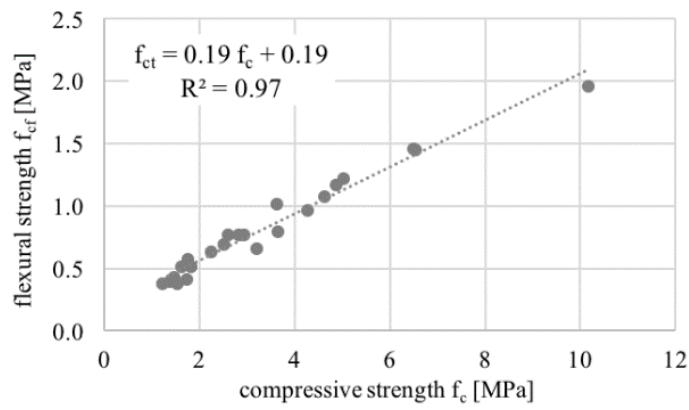

Fig. 7. Comparison of flexural and compressive strength after 28 days of curing.

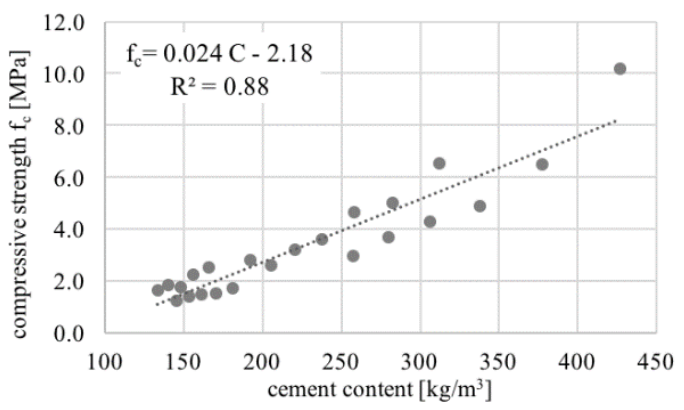

Fig. 8. Impact of cement content on compressive strength after 28 days of curing.

\section{Conclusions}

Soil-cement is a composite made by mixing cement paste with virgin soil. The amount of cement paste and its liquidity, and hence the w/c ratio, have a very significant effect on the liquidity of the homogenised soil-cement mix. In the case of cohesive soil (clay) with the properties described in Table 1, the demand for cement paste fluctuated from 550 to 650 $\mathrm{dm}^{3} / \mathrm{m}^{3}$ depending on the $\mathrm{w} / \mathrm{c}$ ratio, and the $\mathrm{w} / \mathrm{c}$ ratio varied from 3.8 to 1.2 . 
The variability range of the quantitative composition of the soil-cements analysed, which is described above, resulted in differences in the flexural strength achieved, which ranged from 0.4 to $2.0 \mathrm{MPa}$, and also in compressive strength, which ranged from 1.2 to $10.8 \mathrm{MPa}$ after 28 days of curing.

Flexural strength is equal to $19 \%$ of compressive strength and this relationship is essentially independent of the recorded strength levels.

Compressive strength after 28 days of curing depends primarily on the w/c ratio, with the obvious upward trend in strength as the w/c ratio decreases. The strength of the hardened composite is also dependent on the cement paste amount - the less cement paste, the higher the strength, of course within the range considered. The power functions presented above reflect the relationship between the $\mathrm{w} / \mathrm{c}$ ratio and compressive strength very accurately. They are a very useful tool for designing the composition of such composites.

A very universal soil-cement composition parameter is the amount of cement used, which linearly affects the compressive strength of the composite after 28 days of curing. With a cement amount as low as approximately $150 \mathrm{~kg} / \mathrm{m}^{3}$, compressive strengths of slightly less than $2 \mathrm{MPa}$ were achieved, while $420 \mathrm{~kg} / \mathrm{m}^{3}$ of cement resulted in a composite with a compressive strength above $10 \mathrm{MPa}$.

The research results presented above, which of course have a limited application, since they concern cohesive soil (clay) and CEM II/B-S 32.5R cement, enable the precise design of soil-cement compositions, and the composites obtained exhibit properties that make them highly useful as construction materials.

\section{References}

1. M. Topolnicki, Inżynieria Morska i Geotechnika 6, 385-398 (2003)

2. J. Madej, Ulepszanie podłoża (Politechnika Koszalińska, Koszalin, 2015)

3. S. Topoliński, Badanie wytrzymałości kompozytów grunt organiczny-spoiwo cementowe formowanych metodq mieszania, (Uniwersytet Technnologiczno-Przyrodniczy im. Jana i Jędrzeja Śniadeckich, Bydgoszcz, 2014)

4. A. Leśniewska, Wytrzymałościowe $i$ technologiczne aspekty wzmacniania gruntu metodq wgłębnego mieszania na mokro (Politechnika Gdańska, Gdańsk, 2007)

5. P. Kanty, J. Rybak, D. Stefaniuk, Nowoczesne Budownictwo Inżynieryjne 2, 70-75 (2017)

6. Menard Polska Sp. z o.o., Kolumny DSM, www.menard.pl, (January, 2018)

7. P. Łęcki, P. Dojcz, (Instytut Techniki Budowlanej, 2008)

8. M. Topolnicki, XXIV Ogólnopolskie Warsztaty Pracy Projektanta Konstrukcji, 265-280 (2009)

9. P. Rychlewski, Inżynier budownictwa 5, 98-102 (2015)

10. P. Rychlewski, Inżynier budownictwa 2, 92-95 (2013)

11. P. Kanty, Nowoczesne Budownictwo Inżynieryjne 1, 68-73 (2017)

12. M. Topolnicki, Ground Improvement 9, 331-428 (2004)

13. J. Chu, S. Varaksin, U. Klotz, P. Mengé, Construction processes 4, (2009)

14. M. Topolnicki, XXXII Ogólnopolskie Warsztaty Pracy Projektanta Konstrukcji, 1-29 (2017) 